\title{
New constraints on the origins of MARID and PIC rocks based on mineral and bulk-rock geochemical data: Implications for mantle metasomatism and alkaline magmatism
}

\author{
Angus Fitzpayne ${ }^{1 *}$, Andrea Giuliani ${ }^{1,2}$, Janet Hergt ${ }^{1}$, David Phillips ${ }^{1}$, Philip Janney ${ }^{3}$ \\ ${ }^{1}$ KiDs (Kimberlites and Diamonds), School of Earth Sciences, The University of Melbourne, Parkville, 3010 \\ Victoria, Australia (*afitzpayne@student.unimelb.edu.au) \\ ${ }^{2}$ ARC Centre of Excellence for Core to Crust Fluid Systems and GEMOC, Department of Earth and Planetary \\ Sciences, Macquarie University, North Ryde, 2019 New South Wales, Australia \\ ${ }^{3}$ Department of Geological Sciences, University of Cape Town, Rondebosch 7701, South Africa
}

\section{Introduction}

Metasomatism has been implicated as the key process in refertilising mantle domains as a precursor to alkaline magmatism. MARID (Mica-Amphibole-Rutile-Ilmenite-Diopside) and PIC (PhlogopiteIlmenite-Clinopyroxene) xenoliths represent end-member compositions produced by processes of melt/fluid enrichment in the mantle. These rocks have been interpreted as either the products of intense metasomatic alteration of peridotites or as magmatic cumulates in the lithospheric mantle. Irrespective of their formation mechanism(s), the compositions and sources of their parental fluids/melts and the role of MARID-PIC rocks in the genesis of alkaline magmas in intraplate settings remain unclear. To provide new constraints on these outstanding questions, we have studied the petrography and mineral major and trace element chemistry of 26 MARID and PIC xenoliths from southern African kimberlites and orangeites in the Kimberley and Barkly West areas.

\section{Results}

\section{Major Elements}

Mineral major element compositions are distinct in MARID and PIC rocks. MARID clinopyroxene and phlogopite grains are depleted in $\mathrm{Al}_{2} \mathrm{O}_{3}(<0.8 \mathrm{wt} \%$ and $8-12 \mathrm{wt} \%$, respectively) and enriched in $\mathrm{FeO}_{\mathrm{T}}$ (2.9-6.2 $\mathrm{wt} \%$ and 5.3-10.2 wt\%, respectively) relative to PIC minerals (clinopyroxene:1.3-2.5 wt $\% \mathrm{Al}_{2} \mathrm{O}_{3}, 2.9-3.6 \mathrm{wt} \% \mathrm{FeO}_{\mathrm{T}}$; phlogopite: 10.7-12.6 wt $\% \mathrm{Al}_{2} \mathrm{O}_{3}, 3.7-4.8 \mathrm{wt} \% \mathrm{FeO}_{\mathrm{T}}$ ). As such, the compositions of PIC minerals bear several similarities to peridotitic minerals (Fig. 1).

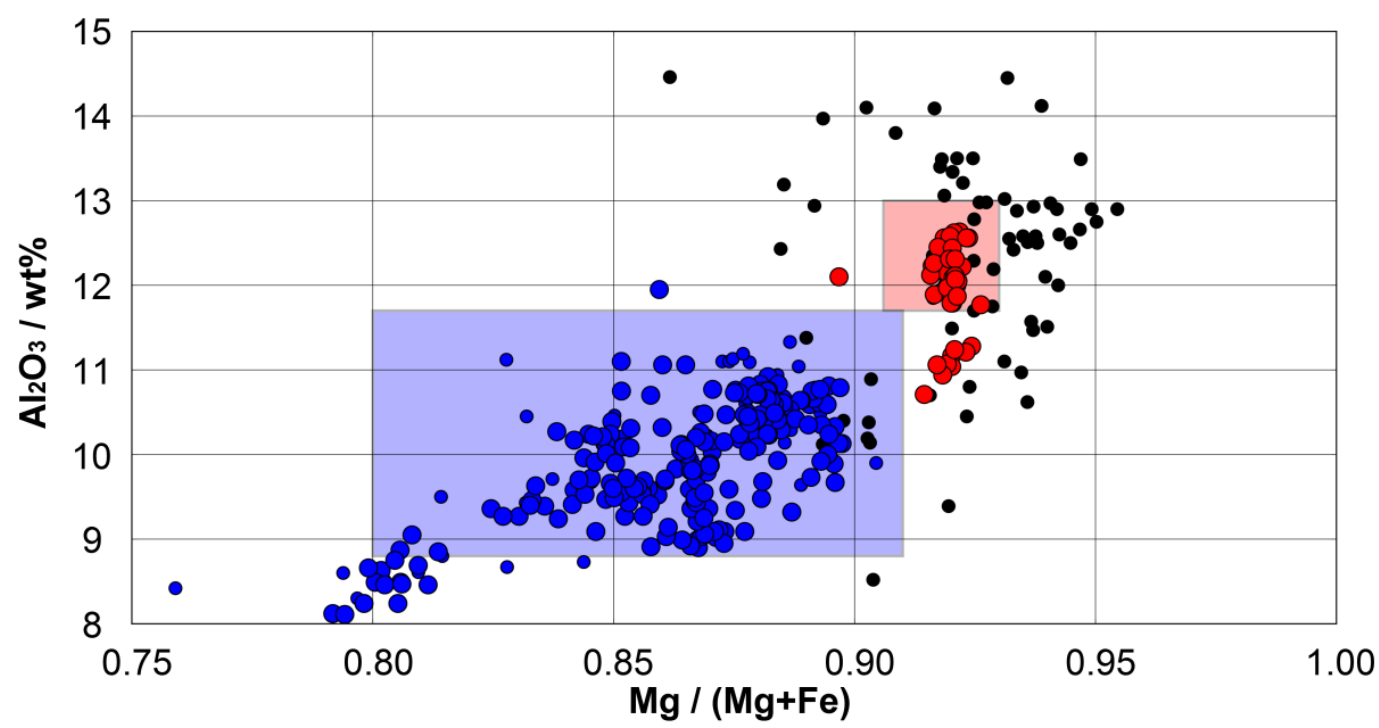

Figure 1: Plot showing phlogopite $\mathrm{Al}_{2} \mathrm{O}_{3}$ vs $\mathrm{Mg} /(\mathrm{Mg}+\mathrm{Fe})$ in MARID and PIC rocks in this study (large blue and red circles, respectively); for comparison, literature MARID (small blue circles) and peridotite (small black circles) data have also been plotted. Blue and red fields represent MARID and PIC phlogopite ranges from Grégoire et al. (2002), respectively. 
Comparisons between the compositions of MARID minerals and their peridotitic counterparts also indicate the possibility that MARID xenoliths form part of the metasomatic continuum that can be observed in peridotite xenoliths (Erlank et al., 1987; Fig. 2).

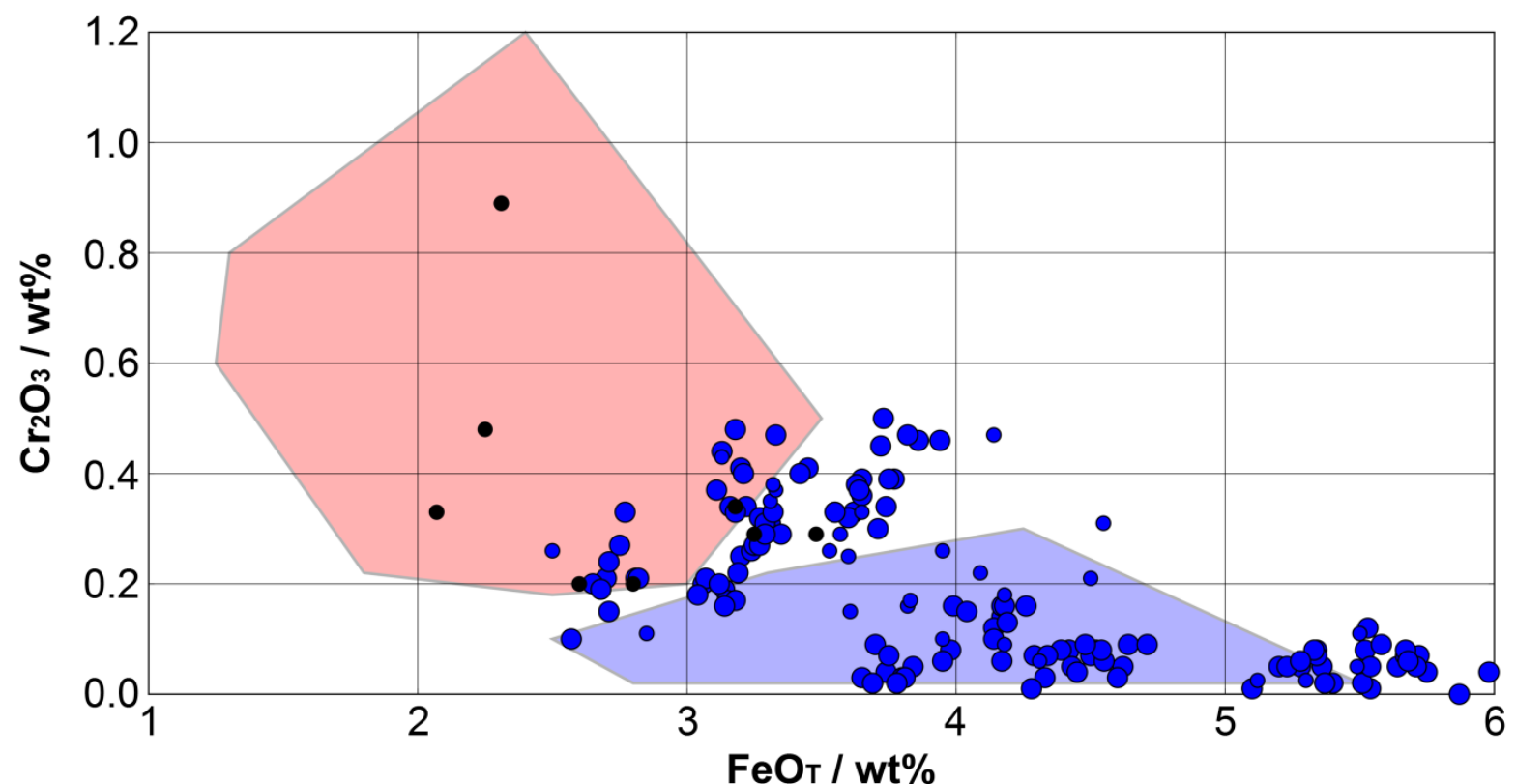

Figure 2: K-richterite $\mathrm{Cr}_{2} \mathrm{O}_{3}$ vs $\mathrm{FeO}_{\mathrm{T}}$ in MARID rocks in this study (large blue circles), literature MARID data (small blue circles), and literature peridotite data (small black circles). Red and blue fields from Erlank et al. (1987), indicating previous ranges of peridotite and MARID K-richterite compositions, respectively.

\section{Trace Elements}

Mineral trace element characteristics, such as clinopyroxene rare earth element (REE) patterns, may also be used to distinguish MARID and PIC rocks (chondrite-normalised $\mathrm{Ce} / \mathrm{Yb}$ 16-60 and 9-21, respectively). Moreover, similar trace element patterns to MARID clinopyroxene can be observed in peridotitic and eclogitic clinopyroxene samples from many locations within and external to southern Africa (Fig. 3), including several off-craton localities (e.g. Kerguelen islands: Grégoire et al., 2000; Namaqua-Natal mobile belt: Le Roex and Class, 2016).
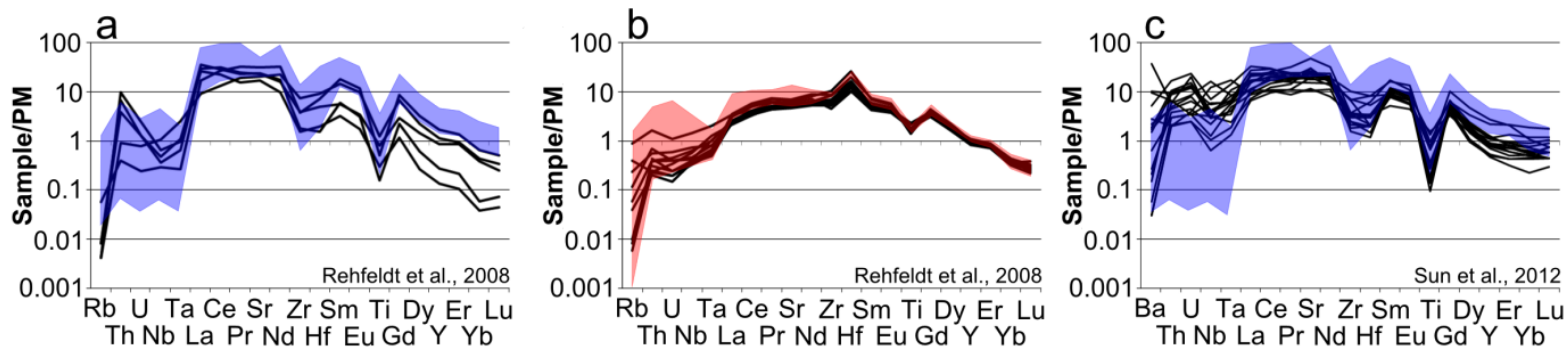

Figure 3: Primitive mantle normalised trace element diagrams for clinopyroxene from dunite, wehrlite (a) and websterite (b) xenoliths from the Kimberley kimberlites (data from Rehfeldt et al., 2008), and harzburgite xenoliths from the North China craton (c; data from Sun et al., 2012). Blue and red fields indicate ranges of MARID and PIC clinopyroxenes analysed in this study, respectively. Normalising values from McDonough and Sun (1995).

\section{Bulk Rock reconstructions}

Bulk rock reconstructions were performed employing mineral modal abundances and average mineral major and trace element compositions. The average reconstructed MARID composition resembles published whole-MARID analyses (e.g., Grégoire et al., 2002). Some trace elements (e.g., REEs) are less abundant in the reconstructions, owing to the effective removal of secondary trace element- 
enriched components such as apatite (occurring in veins, for example) that are unrelated to the primary MARID paragenesis.

\section{Discussion}

The major element compositions of phlogopite and clinopyroxene grains in PICs are similar to those in metasomatised peridotites entrained by southern African kimberlites. Furthermore, all silicate MARID minerals exhibit broader compositional ranges than previously reported, which also partly overlap those in peridotites (Fig. 2). The overlap in compositions necessitates reevaluation of a genetic link between MARID/PIC rocks and metasomatised peridotites. Similarities in the trace element compositions of MARID and peridotitic clinopyroxene from other on- and off-craton localities also indicate that the infiltration of MARID-like fluids may be a ubiquitous metasomatic process in the lithospheric mantle (Fig. 3). The variation in the lithospheric mantle setting/age/thickness hosting these clinopyroxenes suggests that MARID rocks cannot be genetically linked to kimberlite magmas; they are more likely to be formed by interactions with more typical mantle fluids that are mobilised during regional tectono-magmatic events.

The bulk-rock reconstructions of MARID and PIC samples presented here exhibit positive HFSE anomalies, which resemble bulk-rock analyses of MARID and PIC xenoliths performed by Grégoire et al. (2002), and are unusual in mantle-derived rocks. Bulk-rock geochemical enrichments indicate that the metasomatic fluid responsible for MARID genesis must be a HFSE-LILE-enriched silicate melt, which could denote a group II kimberlite (orangeite) melt. However, available age constraints indicate MARID genesis prior to orangeite magmatism, suggesting MARIDs are more likely to be the source of such alkaline rocks (Giuliani et al., 2015). A comparison of MARID bulk-rock and average mineral compositions with published data on alkaline volcanic rocks implicates melting of the silicate components of MARID rocks in the creation of the major and trace element characteristics of alkaline magmas belonging to the lamproite clan (e.g., lamproites, orangeites).

\section{References}

Erlank, A., Waters, F., Hawkesworth, C., Haggerty, S., Allsopp, H., Rickard, R., \& Menzies, M. (1987). Evidence for mantle metasomatism in peridotite nodules from the Kimberley pipes, South Africa. Mantle metasomatism, 221-311.

Giuliani, A., Phillips, D., Woodhead, J. D., Kamenetsky, V. S., Fiorentini, M. L., Maas, R., Soltys, A., Armstrong, R. A. (2015). Did diamond-bearing orangeites originate from MARID-veined peridotites in the lithospheric mantle? Nature Communications, 6, 6837.

Grégoire, M., Moine, B., O’Reilly, S. Y., Cottin, J., \& Giret, A. (2000). Trace element residence and partitioning in mantle xenoliths metasomatized by highly alkaline, silicate-and carbonate-rich melts (Kerguelen Islands, Indian Ocean). Journal of Petrology, 41(4), 477-509.

Grégoire, M., Bell, D., \& Le Roex, A. (2002). Trace element geochemistry of phlogopite-rich mafic mantle xenoliths: their classification and their relationship to phlogopite-bearing peridotites and kimberlites revisited. Contributions to Mineralogy and Petrology, 142(5), 603-625.

le Roex, A., \& Class, C. (2016). Metasomatic enrichment of Proterozoic mantle south of the Kaapvaal Craton, South Africa: origin of sinusoidal REE patterns in clinopyroxene and garnet. Contributions to Mineralogy and Petrology, 171(2), 1-24.

McDonough, W. F., Sun, S-s. (1995). The composition of the Earth. Chemical Geology, 120, 223253.

Rehfeldt, T., Foley, S. F., Jacob, D. E., Carlson, R. W., \& Lowry, D. (2008). Contrasting types of metasomatism in dunite, wehrlite and websterite xenoliths from Kimberley, South Africa. Geochimica et Cosmochimica Acta, 72(23), 5722-5756.

Sun, J., Liu, C.-Z., Wu, F.-Y., Yang, Y.-H., \& Chu, Z.-Y. (2012). Metasomatic origin of clinopyroxene in Archean mantle xenoliths from Hebi, North China Craton: Trace-element and Srisotope constraints. Chemical Geology, 328, 123-136. 